\title{
California set to cash in on British discovery
}

LAST month the Scripps Clinic and Research Foundation in La Jolla, California, announced that it is going into partnership with the pharmaceutical company Miles Laboratories to provide laboratory testing services and prepare immunochemical materials for research scientists and biochemical manufacturers.

The new company will have a staff of about a dozen scientists and will also be able to call on the services of over 150 scientists at Scripps on a consultancy basis. It will offer a range of testing services and products in immunology, endocrinology and toxicology. And one of its most active fields promises to be the rapidly-growing area of monoclonal antibodies. These are antibodies produced by a technique developed a few years ago by Dr Cesar Milstein and Dr George Kohler at the Medical Research Council's Molecular Biology Laboratory in Cambridge, UK. It allows antibodies tailored to identify specific antigens to be produced in relatively large quantities, avoiding many of the uncertainties involved in conventional techniques of antibody production from animal serum.

Already the availability of these techniques and the resulting antibodies has led to what one observer describes as a virtual explosion of interest by research scientists. This has been paralleled, almost simultaneously, by the growth of commercial interest in what promises to be a lucrative range of applications. But although the original research was funded by the British taxpayer, for one reason or another, the National Research Development Corporation did not take out early patents on the techniques and the UK may therefore have forfeited any royalty rights which, some observers believe, could eventually have totalled hundreds of thousands of pounds.

The technique which the Cambridge scientists developed involved fusing two cells, one-taken, for example, from the spleen of a mouse-that produces a range of antibodies (but would be relatively short-lived) and the other a rapidly reproducing tumour cell. The resulting hybridoma cells are separated according to the particular antibodies that they produce, and each cell strain can be cloned to produce a pure source of a single antibody.

For scientists, the use of monoclonal antibodies as a labelling technique (since each antibody will only recognise a particular molecule) is proving to have a wide variety of uses. These range from studies of the structure of cell membranes, to the search for viruses that may be associated with the growth of tumours.
Has Britain lost large potential royalties through a failure to recognise the commercial potential of antibodies? David Dickson reports

Commercial interest in potential applications has been equally swift. The most immediate applications lie in the field of screening, for example in the early detection of cancer, or of foetal abnormalities (since foetal cells can be identified at an early stage in the mother's blood by looking out for genetic material from the father). Other uses range from tissue typing to assisting in the search for new vaccines.

Recognising the great potential of monoclonal antibodies, many large medical instrument and pharmaceutical manufacturers are now eager to enter the field. Some have been working on the techniques in their own laboratories; others-as with Miles Laboratories-by tapping into the expertise of the academic community.

"The type of work which we will be doing in this field will be dictated by the needs of the complex of companies under the Bayer (parent company of Miles) umbrella, for which we will carry out research on a contract basis," says Dr Ernest Tucker, director of Scripps' Immunology Reference Laboratory, which will be a division of the new company.

"These companies will come to us with specific needs for antibodies. And since we are an independent company, we will be able to carry out research at the request of other companies too. It is much more efficient to do it this way, since the support of basic research is very expensive."

As well as established companies, the applications of monoclonal antibodies is also attracting the interest of the venture capital market, a booming business in the US following recent changes in capital gains tax and security laws. Like recombinant DNA research, it is a field ripe for swift marriages between sophisticated science and ambitious entrepreneurship but the pay-offs seem at present to be much closer to fruition, while at the research level at least, the field is relatively free of federal regulations.

A typical creation of the entrepreneurial spirit is Hybritech Inc., a company set up in San Diego earlier this year by the west coast venture capital firm Kleiner and Perkins (which also provided much of the initial capital for the genetic engineering firms Cetus and Genentech).

Hybritech has already announced plans for producing and marketing antibodies for detecting hepatitis, a first foray into a clinical diagnostic market where current sales, according to Hybritech president Howard F. Greene, are around $\$ 200$ million a year, and expanding rapidly. Mr Greene predicts that the return on investment for successful research could be as much as five times higher than that in the electronics field. "Already about $90 \%$ of the major companies in the diagnostic business have called us, expressing an interest in our work. They are all at various stages of looking at programmes in this area, but the feedback seems to be that the large corporations are not moving with the speed and flexibility made possible by venture capital operations," Mr Greene told Nature last week.

The growth of demand for monoclonal antibodies has caused its own logistical problems within the scientific community. Many laboratories offer the hybridoma cells that they have developed to other research workers in the field on request, but this is consuming a large amount of time and energy.

Pressure is now growing for a centralised store of characterised hybridomas. Already a number of cell centres, such as the cell distribution centre at the Salk Institute in San Diego, have a growing number of such cells on their lists. Some scientists are now calling for a new centre, possibly financed by the NIH, to store and distribute hybridomas.

"What seems to be needed is a central depository which would maintain cells that have been carefully characterised and presented by research workers, thawing them out occasionally to check that the characterisation has been maintained," says Dr Hilary Koprowski of the Wistar Institute in Philadelphia. "The time seems ripe for a conference of people interested in the organisation of such as depository, deciding what types of cultures should be accepted, how they should be characterised, and so on."

One problem that a depository would have to face, however, is how it should deal with requests from private companies. With substantial profits looming on the horizon- "Somebody is going to make money in the diagnostic business from this technique," says Jerome Goldstein, head of the Clinical Assays Division of Baxter Travenal Laboratories-licensing of hybridomas promises to become a lucrative business.

At Standford University in California, scientists who have provided hybridomas to Salk's Cell Distribution Center have required that any research 
workers requesting a sample of the cells sign a waiver promising not to use the cells, or the antibodies produced from them, for commercial advantage. The university itself is currently negotiating with a number of pharmaceutical and medical instrument manufacturers on terms for supplying them with specific hybridomas and antibodies developed in the university laboratories. Dr Neil Reimers, head of the university's technology licensing office, sees that as providing the university with a steady stream of income under an arrangement agreed with the National Institutes of Health, which provided much of the funding for the original research.

Whether or not Dr Milstein's original work in Cambridge could have been patented is still hotly disputed. Some claim that, as the application of standard cell fusion techniques is in wide use around the world, there is nothing inherently patentable about $\mathrm{Dr}$ Milstein's use of the hybridoma (although novel hybrid cell lines result- ing from the techniques can, it is generally agreed, be patented).

Others, however, feel that as a sufficiently novel application of the techniques, a patent might indeed have been granted, requiring royalties to be paid to anyone using the techniques for commercial purposes.

But the net result is that, like penicillin and other similar stories, monoclonal antibodies may join the list of the ones that got away from the UK.

\section{Italy's nuclear supremo goes for alternatives}

\section{The new chairman of Italy's nuclear energy committee plans to spend as much on alternative sources as nuclear power, writes Robert Walgate}

For the first time in its history, the Italian National Committee for Nuclear Energy, CNEN, has received money to spend on the research development and promotion of alternative (non-nuclear) sources of energy. On 28 May, the outgoing coalition voted 5 billion lire (about $£ 3$ million) to CNEN to spend mainly on solar and wind power and on energy conservation.

The initiative is the work of CNEN's new Chairman, appointed on 1 February, Dr Umberto Colombo, previously research director of the firm Montedison. Colombo joined CNEN on condition that alternative sources would be included, and the 5 billion lire, he told Nature last week, is only the beginning.

"In Italy there has been no focal point for an energy policy" said Dr Colombo. "We want to become the focal point for all sources of energy which are alternatives to hydrocarbons."

At present, three ministers have partial responsibility for energy policy in Italy: the Minister for Industry supervises CNEN and the Ente Nazionale per l'Energia Elettrica (ENEL), which has responsibility for electricity supply; the Minister of Culture and Scientific Research directs the central body organising basic research in Italy, the Consiglio Nazionale delle Ricerche (CNR); and the Minister of State Participations has responsibility for the Ente Nazionale Idrocarbi (ENI) and the Istituto per la Ricostruzione Industriale (IRI); all of these being bodies with a more or less great interest in energy policy. The Minister for Industry has the largest responsibility -establishing the national energy

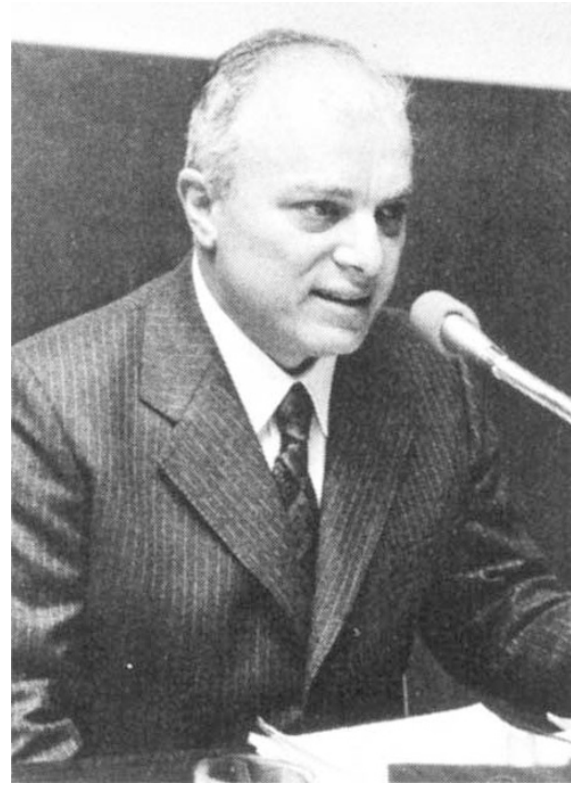

Colombo: "We might even be able to do without fast breeders"

plan, versions of which were published in 1975 and 1977.

"I want to make CNEN the entity responsible for all alternative sources, so that ENI remains responsible for fossil fuels, ENEL for electricity, and CNEN for R \& D and promotion of nuclear and non-nuclear alternative sources, including the most important alternative-energy conservation."

The CNR is also undertaking an energy research project, but Colombo does not foresee conflict, rather coordination: "CNR is more involved universities; our contact is more with with fundamental research and industry". ENEL and ENI have large geothermal projects "so we won't be able to do so much on that-probably we'll concentrate on hot rocks".

Dr Colombo hopes to make a substantial investment in non-nuclear alternative sources. The CNEN budget for 1979 is 200 billion lire (about $£ 115$ million), of which there is only 5 billion lire for alternatives; "but since we have only just started we could hardly be expected to spend much this year". Next year, Colombo hopes to spend 30 billion lire ( $£ 17$ million) on alternatives, and ultimately to reach an expenditure "very close to what we shall be spending on nuclear power".

Would it be possible to spend that much on new sources? "Well if you take some pioneer projects, and you consider that we are not interested so much in basic research as in demonstration units-in conservation, solar, wind, and so forth-it's possible". Clarifying the point, Dr Colombo said he has in mind an ultimate allocation of resources similar to that of the Department of Energy in the US, where nuclear-including fusionstill has more than other sources, but alternative sources have a substantial portion of the budget.

Nevertheless Colombo is convinced that nuclear power must make an increasing contribution to Italy's energy supply; at present one major and three minor reactors supply $0.7 \%$ of Italy's total energy needs and $2.7 \%$ of its electricity. By the year 2000, Colombo would like to see $20 \%$ of Italy's energy needs supplied by nuclear reactors requiring a building rate of two reactors per year; solar power, the main alternative contributor, might supply $7 \%$ by that date, he estimates.

"We do not have North Sea oil, we do not have the gigantic coal fields you have in the UK; at present we are very dependent on imported hydrocarbons. $85 \%$ of our energy is supplied by hydrocarbons, and $76 \%$ is imported energy. This dependence is not acceptable; we are very vulnerable. Our oil bill may go up this year, because of the price increases, by $£ 1$ billion; that's equivalent to exporting another million automobiles, if we want to keep our balance of payments in order . . . so a nuclear programme, as well as a vigorous programme on alternatives, is necessary for Italy."

Colombo makes a fairly classical connection between energy consump- 